\title{
Tulsi (Ocimum sanctum), excellent source of phytochemicals
}

\author{
Borah $\mathrm{R}^{1}$; Biswas S. P. ${ }^{2}$ \\ Department of Life Sciences, Dibrugarh University, Assam, India \\ Email: borahrimlee@gmail.com \\ spbsdu@gmail.com
}

\begin{abstract}
Ocimum sanctum also known as Tulsi or Holybasil is an aromatic plant and it belongs to the family Lamiaceae. It is widely used as medicine to cure various ailments. The objective of the study was to analyse different phytochemical components of tulsi leaf. The dried powder of Tulsi (50g) was placed in the thimble of Soxhlet apparatus and the experiment was done separately for methanol, ethanol and distilled water. The percentage yield was $8 \% \mathrm{w} / \mathrm{w}, 7 \% \mathrm{w} / \mathrm{w}$, and $5 \% \mathrm{w} / \mathrm{w}$ respectively. The study reveals that various secondary metabolites such as carbohydrate, tannin, flavonoids, saponins, glycoside, terpenoid, fatty acids and phenol are present in tulsi leaf extract. From the quantitative analysis it was found that high amount of phenols are present in Tulsi leaf ranging from 1.6 to 7.6 percentages. Consequently the amount of alkaloid and flavonoids ranged from 0.91 to 1.28 and 1.56 to 2.24 percentages respectively. From the GC-MS analysis of methanolic extract three compounds were identified as major constituents viz., Eugenol, Benzene, 1, 2-dimethoxy-4(2-propenyl), $\alpha$-Farnesene and Cyclohexane, 1, 2, 4triethenyl. Thesephyto-chemicals are known to possess antiseptic, analgesic, anti-inflammatory, antimicrobial, antistress, immunomodulatory, hypoglycemic, hypotensive and antioxidant properties. Hence it is more beneficial to use tulsi asan herbal medicine as compare to chemically synthesized drug.
\end{abstract}

Keywords-Ocimum sanctum, phytochemical, medicine, $G C-M S$.

\section{INTRODUCTION}

The plant kingdom is an excellent source of potential drugs and in the recent years there has been an increasing awareness about the importance of medicinal plants. Medicinal plants are rich source of different types of medicines and produce various bioactive molecules. Herbal plant extracts are very useful and are the major sources of medicine which play vital role in controlling various types of pathogens (Doss, 2009) and as growth promoters. These are the cheaper source for therapeutics and viable solution for various pathogens.The medicinal plants extract have now emerged as a good alternative as they are rich in a wide variety of secondary metabolites such as tannins, phenolics, alkaloids and flavonoids etc which enhances growth, innate immune response and disease resistance against pathogenic bacteria in human as well as in different organisms (Edoga et al., 2005). About $80 \%$ of individuals from developed countries use various medicinal plants as traditional medicines as anticancer drugs (Dewick, 1996), antimicrobial drugs (Phillipson, 1996), antifungal and in various proposes. The medicinal plants are rich sources of secondary metabolites which are chemically and taxonomically extremely diverse compounds with obscure function. A large number of phytochemicals are widely uses in human therapy, agriculture, veterinary, various scientific researches and in different areas (Vasu et al., 2009) along with inhibitory effects on all types of microorganisms in vitro (Cowan, 1999).

Ocimum sanctum L. commonly known as holy basil (Tulsi) is an herbaceous perennial, belongs to family Lamiaecae and is considered as one of the most important source of medicine and drugs with many secondarymetabolites and essential oils recommended fortreatment of malaria, diarrhoea, bronchial asthma,dysentery, bronchitis, skin diseases, arthritis, painfuleye disease, chronic fever and eye diseases etc 5,6. Inaddition, Ocimum sanctum also showsanticancerous, antifungal, antimicrobial, antifertility,hepatoprotective, antispasmodic, cardio protective,antiemetic, antidiabitic, analgesic, adaptogenic, anddiaphoretic properties 6-9.The pharmacological studies reported in the present research confirm the therapeutic value of $O$. Sanctum. Therefore, the present study looks into the extraction and preliminary phytochemical analysis of $O$. Sanctum leaves.

\section{MATERIALS AND METHODS}

Collection of plant material: Leaves of Ocimum sanctum L. (tulsi) were collected from different sites of Dibrugarh District, Assam, washed with sterile water and dried in shades. Then the samples were powered in mechanical grinder.

Aqueous, methanol and ethanol extract: The dried tulsi $(50 \mathrm{~g})$ powder was placed in the thimble of Soxhlet 
apparatus and 500- $700 \mathrm{ml}$ of distilled water, methanol and ethanol was used for extraction procedure and the experiment was done separately for all the two solvents and distilled water. The extraction was continued till clear solvent or water was seen in the thimble. The extract was concentrated using rotary evaporator. Then the extract was dried in a digital water bath till a dark green residue was obtained. The percentage yield of the extract was calculated using the following formula:

Final weight of the dried extract

Percentage yield = $\times$

100

\section{Initial weight of the powder}

All the three extracts were kept in separate vials in the refrigerator till further use.

Qualitative phytochemical analysis: The extract was tested following standard biochemical methods as described below.

\section{Test for proteins:}

Biuret's test: $2 \mathrm{ml}$ of Biuret reagent was added to $2 \mathrm{ml}$ of extract. The mixture was shaken well and warm for $5 \mathrm{~min}$. Appearance of red or violet colour indicated presence of proteins.

Million's test: Crude extract was mixed with $2 \mathrm{ml}$ of Millon's reagent, if precipitate appeared which turned red on gentle heating confirmed the presence of protein.

Ninhydrin test:Crude extract was mixed with $2 \mathrm{ml}$ of $0.2 \%$ solution of Ninhydrin and boiled for some time, if violet colour appeared indicating the presence of amino acids and proteins.

\section{Test for carbohydrates:}

Fehling's test: Equal amount of Fehling A and Fehling B reagents were mixed and $2 \mathrm{ml}$ of it was added to the plant extract and then gently heated the sample. Appearance of brick red precipitate indicated the presence of reducing sugars.

Benedict's test: Crude extract when mixed with $2 \mathrm{ml}$ of Benedict's reagent and boiled, a reddish brown precipitate formed which indicated the presence of the carbohydrates. Molisch's test: $2 \mathrm{ml}$ of Molisch's reagent was added to 0.5 $\mathrm{ml}$ of crude extract and the mixture was shaken properly. After that, $2 \mathrm{ml}$ of concentrated $\mathrm{H}_{2} \mathrm{SO}_{4}$ was poured carefully along the side of the test tube. Appearance of a violet ring at the interface indicated the presence of carbohydrate.

Iodine test: $2 \mathrm{ml}$ of iodine solution was mixed with 0.5 to $1 \mathrm{ml}$ of crude extract. A dark blue or purple coloration indicated the presence of the carbohydrate.

Test for phenol: $2 \mathrm{ml}$ of alcohol and 2-3 drops of ferric chloride solution was added to $1 \mathrm{ml}$ of crude extract, bluegreen or black coloration indicated the presence of phenols
Test for tannin: $1 \mathrm{ml}$ of distilled water and 2-3 drops of ferric chloride solution was added to $0.5 \mathrm{ml}$ of crude extract. A black coluration indicated the presence of tannin.

\section{Test for flavonoi ds}

Shinoda test: Crude extract was mixed with small amount of magnesium and concentrated $\mathrm{HCl}$ was added drop wise. Appearance of pink scarlet colour after few minutes indicated the presence of flavonoids.

Alkaline reagent test: $0.5 \mathrm{ml}$ of crude extract was mixed with $2 \mathrm{ml}$ of $2 \%$ solution of $\mathrm{NaOH}$. An intense yellow colour was formed which turned colourless on addition of few drops of diluted acid which indicated the presence of flavonoids.

Test for saponins: $1 \mathrm{ml}$ of crude extract was mixed with $5 \mathrm{ml}$ of distilled water in a test tube and it was shaken vigorously. The formation of stable foam was taken as an indication for the presence of saponins.

\section{Test for glycosides}

Liebermann's test: Crude extract was mixed with each of $2 \mathrm{ml}$ of chloroform and $2 \mathrm{ml}$ of acetic acid. The mixture was cooled in ice. Carefully concentrated $\mathrm{H}_{2} \mathrm{SO}_{4}$ was added. If colour change from violet to blue to green which indicated the presence of steroidal nucleus, i.e., glycone portion of glycoside.

Salkowski's test: $2 \mathrm{ml}$ of chloroform was mixed with crude extract. Then $2 \mathrm{ml}$ of concentrated $\mathrm{H}_{2} \mathrm{SO}_{4}$ was added carefully and shaken gently. A reddish brown colour indicated the presence of glycoside.

Keller-kilani test: $0.5 \mathrm{ml}$ of crude extract was mixed with $2 \mathrm{ml}$ of glacial acetic acid containing 2-3 drops of $2 \%$ solution of $\mathrm{FeCl} 3$. Then $2 \mathrm{ml}$ of concentrated $\mathrm{H}_{2} \mathrm{SO}_{4}$ was poured into the mixture. A brown ring at the interface indicated the presence of cardiac glycosides.

\section{Test for steroid}

(i) $2 \mathrm{ml}$ of chloroform was added to the crude extract of Tulsi. Then $2 \mathrm{ml}$ of each of concentrated $\mathrm{H}_{2} \mathrm{SO}_{4}$ and acetic acid were added into the mixture. The presence of steroids was indicated by appearance of a greenish coloration in the reaction mixture.

(ii) Crude extract was mixed with $2 \mathrm{ml}$ of chloroform and gently added concentrated $\mathrm{H}_{2} \mathrm{SO}_{4}$. A red colour was seen in the lower layer this indicated the presence of steroids.

Test for terpenoids: Crude extract was mixed in $2 \mathrm{ml}$ of chloroform and evaporated to dryness. To this, $2 \mathrm{ml}$ of concentrated $\mathrm{H}_{2} \mathrm{SO}_{4}$ was added and heated for about 2 minutes. Presence of terpenoids was indicated by a greyish colour at the interface.

Test for alkaloids: $2 \mathrm{ml}$ of $1 \% \mathrm{HCl}$ was mixed with crude extract and heated gently. After heating, Mayer's And Wagner's reagents were added to the mixture. If precipitate was observed in the reaction mixture which indicated the presence of alkaloids. 
Test for anthraquinone: $5 \mathrm{ml}$ of chloroform and $5 \mathrm{ml}$ of ammonia solution was added to $0.2 \mathrm{gm}$ of plant extract. Appearance of pink, red or violet colour indicated the presence of anthraquinone.

Oils \& Fats: A small quantity of crude extract was pressed between two filter papers separately. An oily appearance on filter paper indicated the presence of fixed oil and fats.

\section{Test for lactones}

Baljet's test:Crude extract was treated with sodium picrate solution. Presence of lactone was observed by appearance of yellow to orange colour in the mixture.

Quantitative analysis of phytochemical in the plant extract:

Determination of total phenolic contents (Singleton et al., 1999): The amount of total phenol for aqueous, methanol and ethanol extract were determined by FolinCiocalteu reagent method. $2.5 \mathrm{ml}$ of $10 \%$ Folin- Ciocalteu reagentand $2 \mathrm{ml}$ of $2 \% \mathrm{Na}_{2} \mathrm{Co}_{3}$ were added to $0.5 \mathrm{ml}$ of plant extract. The mixture was then incubated at room temperature for 30 minutes. Gallic acid was used as standard $(1 \mathrm{mg} / \mathrm{ml})$. The absorbance of the sample was measured at $765 \mathrm{~nm}$. All the tests were done in triplicates and the results were determined from standard curve and were expressed as gallic acid equivalent $(\mathrm{mg} / \mathrm{g}$ of extracted compound).

Determination of alkaloid (Harborne, 1973): $5 \mathrm{~g}$ of the sample was taken and $200 \mathrm{ml}$ of $10 \%$ acetic acid in ethanol was added to the sample and allowed to stand for 4 hours. Then the solution was filtered and the extract was concentrated on water bath Conc. $\mathrm{NH}_{4}(\mathrm{OH})$ was added drop wise and the whole solution was allowed to settle and the precipitate was then washed with dilute ammonium hydroxide and filtered. The residue was dried and weighed and this was the amount of alkaloid present in the plant material

Determination of flavonoids (Bohm \& KocipaiAbyazan, 1994): $10 \mathrm{~g}$ of plant sample was taken and extracted repeatedly with $100 \mathrm{ml} 80 \%$ methanol. Then the solution was filtered and the filtrate was transferred into an empty crucible and evaporated into dryness over water bath and weighed. The final weight dry weight was amount of flavonoids in the plant sample.

\section{Preparation of stock solution}

The extracts were reconstituted in methanol. Methanolic extracts $(1 \mu \mathrm{l})$ were injected for GC-MS analysis.

Gas Chromatography-Mass Spectrometry analysis
Methanolic extract of the leaves of Ocimum sanctumwas subjected to GC-MS analysis on a GC- MS Clarus 500 Perkin Elmer systemcomprising a AOC- 20i autosampler and gaschromatograph interfaced to a mass spectrometer (GC-MS) instrument employing the followingconditions: Restek RtxR - 5, (30 meter X 0.25 $\mathrm{mm})(5 \%$ diphenyl / 95\% dimethyl polysiloxane), runningin electron impact mode at $70 \mathrm{eV}$; helium (99.999\%) was used as carrier gas at a constant flow of $1 \mathrm{ml} / \mathrm{min}$ and an injection volume of $2.0 \mu \mathrm{l}$ wasemployed(split ratio of 10:1); injector temperature $280^{\circ} \mathrm{C}$. The oven temperature was programmedfrom $50^{\circ} \mathrm{C}$ (for $1 \mathrm{~min}$.), with an increaseof 6 ${ }^{0} \mathrm{C} / \mathrm{min}$ to $280{ }^{0} \mathrm{C}$, then ending with aisothermal for $15 \mathrm{~min}$ at $280^{\circ} \mathrm{C}$. Mass spectra weretaken at $70 \mathrm{eV}$; a 0.5 seconds of scan interval andfragments from 40 to $550 \mathrm{Da}$. Total GC runningtime was 60 minutes.

\section{Identification of Compounds}

Interpretation on mass spectrum GC-MS was conducted using the database of department of Chemistry; Dibrugarh University. The mass spectrum of the unknown component was compared with the spectrum of the known components stored in the department of Chemistry library.

\section{RESULTS}

The yield of residue after Soxhlet extraction and evaporation of $50 \mathrm{gm}$ dried plant leaves in methanol, ethanol and water were as follows:

Table.1: Amount of plant extracts yield percentage in different solvents

\begin{tabular}{|l|l|}
\hline Extract & $\begin{array}{c}\text { Yield amount (\%) } \\
\text { W/W }\end{array}$ \\
\hline Aqueous & $5 \%$ \\
\hline Methanol & $8 \%$ \\
\hline Ethanol & $7 \%$ \\
\hline
\end{tabular}

The phytochemicals analysis in Ocimum sanctum (Tulsi) leave extracts in the two solvents and aqueous conditions were summarized in Table 2. Various bioactive molecules were found in Tulsi leaf extract from the phytochemical screening. The amount of extraction is more in case of organic solvent then that of water. From the quantitative analysis it was found that high amount of phenols are present in Tulsi leaf ranging from 1.6 to 7.6 percentages. Consequently the amount of alkaloid and flavonoids ranged from 0.91 to 1.28 and 1.56 to 2.24 percentages respectively. 


Table.2: Qualitative phytochemical screening methanol extract of tulsi leaf
\begin{tabular}{|l|l|l|l|}
\hline Phytochemicals & $\begin{array}{l}\text { Aqueous } \\
\text { extract }\end{array}$ & $\begin{array}{l}\text { Methanol } \\
\text { extract }\end{array}$ & Ethanol extract \\
\hline Protein & - & - & - \\
\hline Carbohydrate & - & + & + \\
\hline Phenol & + & + & - \\
\hline Tannin & - & + & + \\
\hline Flavonoid & + & + & + \\
\hline Saponin & - & + & + \\
\hline Glycosides & + & + & + \\
\hline Steroid & - & - & - \\
\hline Terpenoid & - & + & + \\
\hline Alkaloid & + & + & + \\
\hline Anthraquinone & - & - & - \\
\hline Fixed oils and fatty acid & - & + & - \\
\hline Test for lactones & - & - & - \\
\hline
\end{tabular}

“+"present, "“-" absent

Table.3: Percentage of total phenolic, alkaloid and flavonoid contents in plant extract

\begin{tabular}{|l|l|l|l|}
\hline Extract & Phenolic & Alkaloid & Flavanoi d \\
\hline Aqueous & $1.61 \pm 0.56$ & $0.91 \pm 0.66$ & $1.56 \pm 0.64$ \\
\hline Methanol & $7.61 \pm 0.55$ & $1.28 \pm 0.03$ & $2.24 \pm 1.02$ \\
& & & \\
\hline Ethanol & $4.61 \pm 0.56$ & $0.94 \pm 0.58$ & $1.91 \pm 0.56$ \\
\hline
\end{tabular}

Each value is the average of three analys is and \pm standard deviation.

Table.4: Chemical constituents and the activity of some of the phytocomponents of Ocimum sanctum

\begin{tabular}{|l|l|l|c|l|l|}
\hline $\begin{array}{l}\text { Sl. } \\
\text { No }\end{array}$ & $\begin{array}{l}\text { Retention time } \\
\text { (unit?) }\end{array}$ & $\begin{array}{l}\text { Name of the } \\
\text { compounds }\end{array}$ & $\begin{array}{l}\text { Molecular } \\
\text { weight }\end{array}$ & $\begin{array}{l}\text { Molecular } \\
\text { formula }\end{array}$ & Activity** \\
\hline 1. & 7.20 & Eugenol & 164 & $\mathrm{C}_{10} \mathrm{H}_{12} \mathrm{O}_{2}$ & $\begin{array}{l}\text { Anti- inflammatory, } \\
\text { antioxidant, anticancer, Acaricide, } \\
\text { Antibacterial,Antispasmodic, } \\
\text { Antiviral, Insecticide }\end{array}$ \\
\hline 2. & 7.70 & $\alpha-$ Farnesene & 93 & $\mathrm{C}_{15} \mathrm{H}_{24}$ & $\begin{array}{l}\text { Acaricide, allergenic, analgesic, } \\
\text { anaesthetic, antibacterial, anti- } \\
\text { inflammatory, antiedemic, antioxidant, } \\
\text { antiviral, antitumor, antiulcer }\end{array}$ \\
\hline 3. & 7.50 & $\begin{array}{l}\text { Benzene, 1, 2- } \\
\text { dimethoxy- } \\
\text { 4-(1-propenyl) }\end{array}$ & 178 & $\begin{array}{l}\mathrm{C}_{11} \mathrm{H}_{14} \mathrm{O}_{2} \\
\text { Insect-attractant, } \\
\text { perfumery, flavour antibacterial, } \\
\text { nematicide }\end{array}$ \\
\hline 4. & 13.36 & $\begin{array}{l}\text { Cyclohexane,1,2,4- } \\
\text { triethenyl }\end{array}$ & 162 & $\mathrm{C}_{12} \mathrm{H}_{18}$ & $\begin{array}{l}\text { Antibacterial, anti-inflammatory, } \\
\text { antiedemic, antispasmodic }\end{array}$ \\
\hline
\end{tabular}

\footnotetext{
**Source: Dr. Duke's phytochemical and ethnobotanical database (online database)
} 


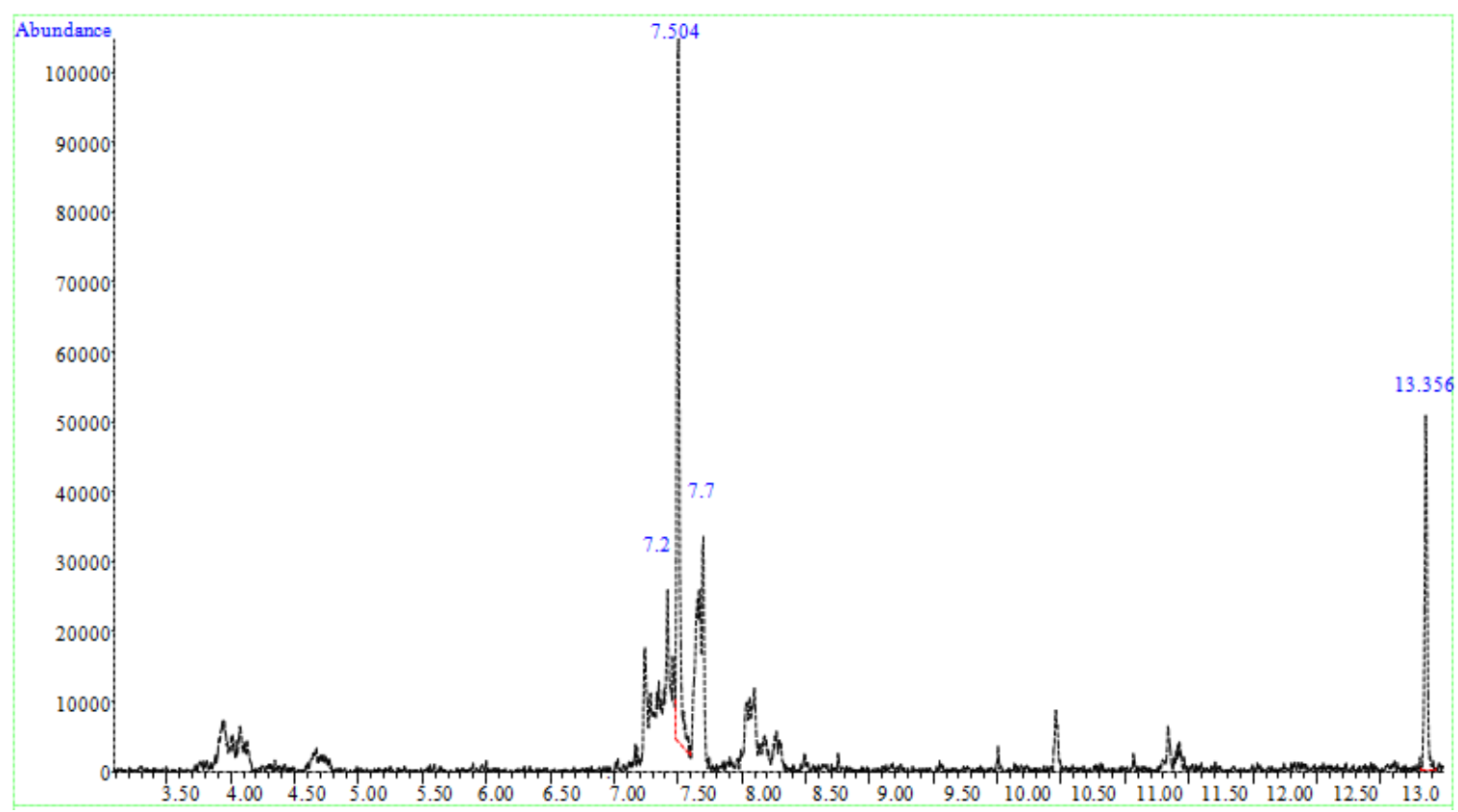

Fig.1: GC-MS chromatogram of the methanolic extract of the leaves of Ocimum sanctum

\section{DISCUSSION}

Ocimum sanctum has various properties such as antistress, antiseptic, analgesic, anti-inflammatory, antimicrobial, immunomodulatory, hypoglycemic, hypotensive, cardioprotective and antioxidant (Williamson, 2002, Tanwar et al., 2015). Eugenol (1-hydroxy-2-methoxy-4allylbenzene), the active constituents present in $O$. sanctum have been found to be largely responsible for the therapeutic potentials (Sailaja et al., 2010). This plant has various properties such as antistress, antiseptic, analgesic, anti-inflammatory, antimicrobial, immunomodulatory, hypoglycemic, hypotensive, cardioprotective and antioxidant (Williamson, 2002, Tanwar et al., 2015). Eugenol (1-hydroxy-2-methoxy-4-allylbenzene), the active constituents present in $O$. sanctum have been found to be largely responsible for the therapeutic potentials (Sailaja et al., 2010).

The study reveals that various secondary metabolites such as carbohydrate, tannin, flavonoids, saponins, glycoside, terpenoid, fatty acids and phenol are present in tulsi leaf extract. Leaves of Ocimum sanctum contain water-soluble phenolic compounds and various other constituents, such as eugenol, methyl eugenol and caryophylllene that may act as an immunostimulant. Saponins act as antihyperlipedemic, hypotensive and cardiodepessive properties (Bairwaet al., 2012). The phytochemical constituents such as alkaloids, steroids, flavanoids, tannins, phenols and several other aromatic compounds of plants serve a defense mechanism against predation by many microorganisms, insects and other herbivore (Bonjar et al., 2004) Glycosides can act as cardiostimulants in cases of cardiac failure (Sood et al., 2005). Tannins have anti diarrheal and haemostasis properties (Asquith et al., 1986). Flavanoids are responsible for antioxidant and immunostimulatory properties. According to Cragg et al., 1999 and Khanna et al., 2003 alkaloids, glycosides, flavanoids and saponins are antibiotic principles of plants and these antibiotic principles are actually the defensive mechanisms of the plants against pathogens.

GC-MS chromatogram of the methanolic extract of Ocimum sanctum showed four major peaks (Figure.1) and has been identified after comparis on of the mass spectra with the department of Chemistry library, DU, indicating the presence of four phytocomponents. It was observed that presence of Eugenol (Synonym: 2-Methoxy- 4-(2propenyl) phenol), Benzene, 1, 2-dimethoxy- 4- (2propenyl) - (synonym: Methyl- Isoeugenol), $\alpha$ - Farnesene and Cyclohexane, 1, 2, 4- triethenyl were the major components in the extract. The phytochemicals that contribute to the medicinal property of the plant leaves is listed in Table No.1. Benzene, 1, 2-dimethoxy- 4-(1propenyl) (Methyl-Isoeugenol) has the property of Antifungal activity (Kurita et al., 1981), Nematicidal activity (Park et al., 2003) and Antifeedant activity (Katsumi, 1987).Eugenol is reported to possess Antimycotic (Azzouz et al., 1982) Antiviral (Bishop, 1995) Desinsection (Konstantopoulou et al., 1992) Antiparasitic (Pandey et al., 2000) Antioxidant (Ou et al., 2006) Anticancer (Hussain et al., 2011) and Ant insect activities(Pessoa et al., 2002).

Leaves extract of $O$. sanctum affected both specific and non-specific immune responses and disease resistance against fungal and bacterial infection(Santra $e t$ al., 2017). It stimulated both antibody response and neutrophil activity. The experimental studies have shown 
that methanolic extract of Ocimum sanctum has anticancer effect by inhibition of nitric oxide synthesis (Kim et al., 1998). The use of medicinal plants acts as a source of antimicrobial agent also for aquaculture. In Macrognathus pancalus, the extract of $O$. sanctum was found to enhance the antibody response (Dugenci et al., 2003). The different leaf extracts of Tulsi (Ocimum sanctum), shows antimicrobial activity against three human pathogens Escherichia coli, Staphylococcus aureus and Candida albicans. (Subramanian et al.,2014). Tulsi oil showed significant anti-inflammatory, analgesic, antipyretic and antimicrobial effects. It has also shown memory enhancing, antifertility, anticataract, antithyroid, antiulcer, antidiabetic, antiarthritic, antiamnesic, antihelmenthic, anticataract, hepatoprotective and no tropic activity (Rajesh et al., 2013). Alcoholic extract increased step down latency and acetyl cholinesterase inhibition and so used in the treatment of cognitive disorders. Ocimum sanctum has been widely employed in traditional medicines. Hence phytochemicals from this plant can be used in variety of disorders afflicting mankind. The herbs are cheap, available in large quantity around us and they pose no danger to the living organisms, the environment and the consumers and hence greatly helpful for living organisms.

\section{CONCLUSION}

The presence of various bioactive compounds in the tulsi leaves justifies the uses for various ailments by living population. The results confirm the use of Ocimum sanctum plant as traditional medicinal properties andsuggest that some of the plant extracts possess compounds with antimicrobial properties that can be used asantimicrobial agents in new drugs for the therapy of infectious diseases caused by various pathogens. It is more beneficial to use tulsi asan herbal medicine as compare to chemically synthesized drug.

\section{ACKNOWLEDGEMENT}

The authors acknowledge their profound gratitude to theDepartment of Life Sciences, Dibrugarh University for providing necessary facilities and encouraging us to carry out the work. The authors are also grateful to the Department of Chemistry, Dibrugarh University permitting for GC-MS analysis and also Thankful to University Grants Commission, Delhi for providing financial support (UGC/NET-JRF Fellowship) to carry out the work.

\section{REFERENCES}

[1] Asquith, T.N. and Butler, L.G., 1986, Interaction of condensed tannins with selected proteins. Phytochemistry, 25(7): 1591-1593.
[2] Azzouz, M.A. and Bullerman, L.B., 1982, Comparative antimycotic effects of selected herbs, spices, plant components and commercial anti fungal agents, Journal of Food Protection, 45(14): 12981301.

[3] Bairwa, M.K, Jakhar1, J.K., Satyanarayana Y and Reddy, A.D. 2012, Animal and plant originated immunostimulant used in aquaculture, Scholars Researchs Library, 2 (3):397-400.

[4] Bishop, C.D., 1995, Antiviral activity of the essential oil of Melaleuca alternifolia (Maiden and Betche) Cheel (tea tree) against tobacco mosaic virus, Journal of Essential Oil Research,7(6): 641644.

[5] Boham, B.A. and Kocipai, A.R., 1994, Flavanoids and condense tannins from leaves of Hawaiian Vaccinium vaticulatum and $V$. Calicinium. Pacific Science, 48: 458-463.

[6] Bonjar, GHS., Nik, AK. and Aghighi, S., 2004, Journal of Biological Science, 4, 405-412.

[7] Cowan, M.M. 1999, Plant products as antimicrobial agents., Clinical Microbiological Review: 564-582.

[8] Dewick, P.M., 1996, Tumor inhibition from plants: Tease and Evans. Pharmacognosy.

[9] Doss, A., 2009, Preliminary phytochemical screening of some Indian medicinal plants. Ancient Science of Life, 29(2): 12-16.

[10] Dugenci, S.K., Arda, N. and Candan, A., 2003, Some medicinal plants as immunostimulant for fish. Journal of Ethnopharmacology, 88 (1): 99-106.

[11] Edoga, H.O., Okwu, D.E., Mbaebie, B.O. 2005, Phytochemicals constituents of some Nigerian medicinal plants. African Journal of Biotechnology, 4(7): 685-688.

[12] Harborne, J.B., 1973, Phytochemical methods. London. Chapman and Hall, Ltd.

[13] Hussain, A., Brahmbhatt, K. And Priyani, A., 2011, Eugenol enhances the chemotherapeutic potential of gemcitabine and induce anticarcinogenic and antiinflammatory activity in human cervical cancer cells, Cancer Biother Radiopharm, 26(5): 519-27.

[14] Katsumi, Y., 1987, Minor components from growing buds of Artemisia capillaris that acts as insect antifeedants, Journal of Agricultural and Food Chemistry, 35(6): 889-891.

[15] Khanna, N. And Bhatia, J., 2003, Action of Ocimum sanctum (Tulsi) in mice: possible mechanism involved. J Ethnopharmacology, 88(2-3): 293-296.

[16] Kim OK, Murakami A, Nakamura Y, Ohighashi H. (1998), Screening of edible Japanese Plants for nitric oxide generation inhibitory activities in RAW 246.7 cells. Cancer Let; 125 (1-2): 199-207. 
[17] Konstantopoulou, I., Vassilopoulou, L. and Mavraganit, P., 1992, Insecticidal effects of essential oils. A study of the effects of essential oils extracted from eleven Greek aromatic plants on Drosophila aurora, Experiential, 48(6): 616-619.

[18] Kurita, N., Miyaji, M., Kurane, R. and Takahara, Y., 1981, Antifungal activity of components of essential oils, Agricultural Biology and Chemistry, 45: 945-952.

[19] Ou, H.C., Chou, FI. And Lin, T.M., 2006, Protective effects of eugenol against oxidized LDLinduced cytotoxicity and adhesion molecule expression in endothelial cell, Food and Chemical Toxicology, 44(9): 1485-595.

[20] Pandey, R., Kalra, A. and Tandon, S., 2000, Essential oil compounds as potent source of nematicidal compounds, Journal of Phytopathology, 148(7-8): 501-502.

[21] Park, B.S., Lee, K.G., Shibamoto, T., Lee, S.E. and Takeoka, G.R., 2003,Antioxidant activity and characterization of volatile constituents of taheebo (Tabebuia impetiginosa Martius ex DC), Journal of Agricultural and Food Chemistry, 51: 295-300.

[22] Pessoa, L.M., Morais, S.M. and Bevilaqua, C.M., 2002, Anthelmintic activity of essential oil of Ocimum gratissimum Linn and eugenol against Haemonchus contortus, Vet Parasitol, 109(1-2): 5963.

[23] Rajesh, H., Rao, S.N., Prathima, K., Shetty , Megha rani, N., Rejeesh, E. P. and Lovely, N. J., 2013, Phytochemical analysis of aqueous extract of Ocimum sanctum linn,International journal of universal pharmacy and bio sciences, 2(2):462-468.

[24] 24. Santra, S., Sinha, A. and Mondal, C., 2017, Effect of Herbal plant (Tulsi) against Common Disease in Gold Fish, Carassius Auratus (Linn. 1758), International Journal of Latest Technology in Engineering, Management \& Applied Science (IJLTEMAS), 6 (2): 29-31.

[25] Sailaja, I., Shaker, I.A. and Ratna, Y.K., 2010, Antioxidant activity and phenolic contents in Ocimum sanctum and Ocimum bascilicum. Asian Journal of Bio Science, 5(1): 1-5.

[26] Singleton, V.L., Orthofer, R. and LamuelaRaventos, R.M., 1999, Analysis of total phenols and other oxidation substrates and antioxidants by means of Folin-Ciocalteu reagent. Methods of Enzymology, 299: 152-178.

[27] Sood, S., Narang, D., Dinda, A.k. and Maulik, S.K., 2005, Chronic oral administration of Ocimum sanctum linn augments endogenous antioxidants and prevents isoproternol- induced myocardial necrosis in rats, Journal of Pharmaco and Pharmacology, 57 (1): 127-133.

[28] Subramanian, G., Tewari, B.B., Gomathinayagam, R., 2014,Studies of Antimicrobial Properties of Different Leaf Extract of Tulsi (Ocimum tenuiflorum) against Human Pathogens. American International Journal of Contemporary Research, 4(8): 149-157.

[29] Tanwar, R., Pahare, A. and Naqvi, S. M. A., 2015, Ocimum sanctum (tulsi), excellent source of phytochemicals. Indo American Journal of Pharmaceutical Research, 12(5): 2231-6876.

[30] Vasu, K., Goud, J.V., Suryam, A., Singara and Chary, M.A., 2009,Biomolecular and phytochemical analyses of three aquaticangiosperms. African Journal Microbiology Research, 3(8):418-421.

[31] Williamson, E. M., 2002, Ocimum in major herbs of Ayurveda. Churchhill Living stone publication, London, 201-205. 